\title{
Taistelutahtoinen, sapenkarvainen romantikko
}

\section{Panu Rajala: Suomussalmen sulttaani: Ilmari Kiannon elämä. Kirjokansi, 154. Helsinki: SKS, 2018, 525 s.}

Professori Panu Rajala on tarttunut elämäkerturina kirjailija Ilmari Kiantoon (1874-1970). Suomalaisen kirjallisuuden seuran julkaisema järeä teos kokoaa kansiinsa Kiannon liki satavuotisen elontaipaleen muun muassa Pulkkilassa, Suomussalmella, Helsingissä ja Karjalan kannaksella. Piirtyy kuva ristiriitaisesta ja itsekeskeisestä, yhtä aikaa ärsyttävästä ja hieman poloisesta kirjailijahahmosta, jonka kohdalla ilmaus "levoton sielu" on laimea.

Otetaan aivan alkuun tuokiokuva tämän arvion kirjoittajan omasta taipaleesta. Ollaan vuosituhannen alussa. Työskentelen muutaman vuoden Suomussalmella kunnan ja Euroopan aluekehitysrahaston projektissa, jossa tarkoituksena on nostaa esille oman paikkakunnan kirjailijaa, siis juuri Kiantoa, esimerkiksi kulttuurivaihdon ja -matkailun merkeissä. Rakennetaan näyttelyä, matkaillaan Vienassa Kiannon jalanjäljillä, taidetaan ajaa porollakin. Projekti herättää paikallisesti mielenkiintoa mutta myös toisenlaisia ajatuksia. Eräs kanssaihminen pukee sen toisen näkökulman sanoiksi koko lailla suoraan: "Antaisivat jo olla".

Kianto tietysti muistetaan kansankuvauksen klassikoistaan Punainen viiva (1909) ja Ryysyrannan Jooseppi (1924). Kuten Rajala antaa ymmärtää, nämä Kiannon pääteokset kestävät ajasta aikaan, kuten kestää sellainen merkittävä kirjallisuus, joka ei toteuta vain karkeaa monomaanista tendenssiä tai viihdytystä. Romaanien tulkintamahdollisuudet avautuvat yhä laajasti kuin Kainuun sininen vaaramaisema, kun ajetaan Viitostietä ohi Ristijärven ja Hyrynsalmen hiipuvien taajamien kohti Kiantajärven kainalossa sinnittelevää Ämmänsaarta. Suomussalmelta on matkaa itärajalle vain lyhyt hujaus, mutta lehmän ja Topin hengiltä lyövä karhu ei ehkä symboloikaan itänaapuria - eikä köyhälistön syveneviä pettymyksiä tarkasteleva kertoja varsinaisesti asetu mihinkään poliittiseen positioon. Kuten Rajala kirjoittaa: "Kianto on vaihtuvien mielialojen, vastakkaisten kannanottojen, repäisevien tuntojen ja aitojen myötäelämysten kirjailija, jota ei saa mahtumaan yhden tyylilajin karsinaan" (331).

Näiden kahden kanonisoidun romaanin ohella Kiannon muu tuotanto on sanalla sanoen valtava. On matkakertomuksia ja tunnustuksia, on tuokiokuvia niin eliitin kuin rahvaan elämästä, on sotatorven törähdyksiä ja pateettisuudessaan vaikuttava maakuntalaulu, "Nälkämaan laulu”. Voi ajatella, että Kianto kirjoitti maanisesti - tai sitten voi ajatella, että siinä työskenteli ammattikirjoit- 
taja, jonka leipä oli kiinni kynästä ja kirjoituskoneesta. Ja sitä leipäḧhän Kianto hankki myös muuten, muun muassa piinaavalla yhteydenpidolla kustantajiinsa, yrityksiin ja muihin potentiaalisiin kontakteihinsa yhteiskunnan ylätasoilla. Rajala kuvaa kiinnostavasti erityisesti Kiannon pitkäaikaisen kustantamon Otavan roolia. Vaikka Kiannon taloudenpito oli holtitonta ja hän hyödynsi myös muita kustantajia, Heikki Reenpään johdolla Otava tuki kirjailijaansa merkittävästi. Kiitosta siitä ei tainnut tulla.

Jos lukijalla on Kiannon edesottamuksista esitietoja, Rajalan teoksen uutuusarvo ei liene kovin vahva. Lukijalle, jolle korpikirjailija on vielä vieras, kyse on puolestaan epäilemättä melkoisen huimasta tarinasta omantunnon avioliittoineen, sihteereineen ja A-, B- ja C-sarjan kaksinetoista lapsineen. Päivälehdistössä julkaistuissa Rajalan teoksen arvioissa Kiannon moninaisiin naisseikkailuihin onkin viittauksenomaisesti luotu \#metoo-liikehdinnän valotusta. Rajala selvittää Kiannon naisseikkailuita sen kummemmin tuomitsematta, vain joitain sarkastisia välikommentteja esittäen. Lapsista eniten huomiota saa kuopus Raija-Liisa Kianto, joka esipuheen mukaan on myötävaikuttanut siihen, että Rajala on tähän aiheeseen tarttunut.

Naisasioissa riittääkin puitavaa, mutta kirjallisuuden ja sen tutkimuksen näkökulmasta Kianto-elämäkerta herättää toisenlaisia kysymyksiä. Kun astuu lukukokemukseen sillä kirjallisuudentutkimuksen tulokulmalla, että teoksia ja tekijöitä ei tulisi sekoittaa toisiinsa eikä käyttää ainakaan naiiviin keskinäiseen selittämiseen, joutuu Rajalan elämäkertaa lukiessa hienoisiin ongelmiin. Rajalan huomiot ja tulkinnat Kiannon tuotannosta tuntuvat tuoreilta eivätkä ole vailla kriittisyyttä. Välillä on kuitenkin vaikea pysyä kärryillä siitä, onko puhe lihaa ja verta olevasta kirjailijasta vai jonkin teoksen minähenkilöstä tai kertojasta. Kiannon kohdalla tämä rajanveto on tietysti aivan erityisen vaikeaa, ovathan Kiannon teokset täynnä alleviivattua omaelämäkerrallisuutta ja nimenomaisesti kirjailijaan itseensä viittaavia salanimiä. On helppo yhtyä siihen, että Kianto loi uudenlaisen, julkisuushakuisen ja kaiken tunnustavan kirjailijatyypin ja että Kiannon teokset ja elämä muodostavat kokonaisteoksen. Tuntuu kuitenkin, että tästä tematiikasta jää vielä sananen sanomatta.

Joka tapauksessa Rajalan teos Kiannosta on vaikuttavan tarkka. Voi vain uumoilla, millaisen sukelluksen eri arkistoihin työ on vaatinut. Mieleen jää erityisesti kuvaus, miten jokin Kiannon elämän todellinen tapahtuma tulee tuotannossa esille eri tavoin vuosien varrella niin, että kirjailija itsekin muuttaa ja entisestään värittää tarinaa matkan varrella. Tyyliltään teos on helppolukuinen. Vain hetkittäin lähennellään kohteen koukeroista, nykylukijan näkökulmasta usein uuvuttavaa ilmaisutapaa. Kuvitus on havainnollista, ja sitä on sopivasti. Pienenä kauneusvirheenä lähdeluetteloista näyttäisi puuttuvan Eero Marttisen laatima Kiannon "suppea elämäkerta" vuodelta 2010, vaikka sellainen mainitaan tekstissä. Suomussalmelaisen Kianto-tuntijan, kirjailija Jalo Heikkisen työ mainitaan useamman kerran. 
Erityisen onnistunut mielestäni on Rajalan teokseensa luoma rakenne, jossa temaattinen jaottelu ja aikakronologia limittyvät. Luvut keskittyvät kukin omaan teemaansa, ja silti syntyy kuva kronologisesta elämäkerrallisesta eteenpäin menemisestä. Taitava jäsennys herättää mielikuvan vaivattomuudesta ja luontevuudesta, vaikka epäilemättä kyseessä on mittavan työn tulos. Kirjailijakoti-Turjanlinnan tuho ja Kiannon tuomio sotapetoksen yrityksestä ovat kulminaatio, jonka jälkeen kerronta tuntuu lähtevän kiirehtimään kuin elämäkerturi olisi jo hieman alkanut kyllästyä kovaääniseen kohteeseensa. Lopuksi Kianto saatellaan kevätjäitä pitkin Kiantajärven Niettussaaren hautaansa, lopultakin lepäämään.

Olisiko ollut jo aika antaa Kiannon olla? Rajalan elämäkerran kuvaama maisema on toki monilta osin jo kuljettu ja koluttu, mutta Suomussalmen sulttaani on kuitenkin ehjä, paneutuva kokonaisesitys, joka tarjoaa myös oivalluksia.

Marianne Roivas 